\title{
JOHN GRIEVE'S CORRESPONDENCE WITH JOSEPH BLACK AND SOME CONTEMPORANEOUS RUSSO-SCOTTISH MEDICAL INTERCOMMUNICATION
}

On 28 January 1783, Joseph Black, professor of medicine and chemistry at Edinburgh Univeristy, and William Robertson, its principal, were elected honorary foreign members of the Russian Academy of Sciences. In May of that year, John Grieve, a Scottish doctor returning to Britain from service with the Russian army, wrote from Riga, as "a scholar to his old master", to inform Black of arrangements for delivering the Academy's diploma, which he conveyed as far as London. ${ }^{1}$ To understand the context of their subsequent correspondence and the development of Russo-Scottish medical intercommunication, a brief outline of relevant contacts between the two countries is necessary.

In July 1762, a revolution occurred in Russia: Peter III, the feeble-minded tsar, was murdered at the instigation of his wife Catherine, who succeeded to the throne. Scottish doctors, through introductions and family connexions, had made their presence strongly felt in Russian medical life. One of them, James Mounsey, the late tsar's senior physician and director of the country's entire medical services, prudently chose to retire to Scotland at this juncture, on health grounds. Evidently, the situation had soon stabilized, for in September 1766, John Rogerson, whose mother was Mounsey's half-sister, arrived in Russia recommended by Mounsey. Licensed to practise, Rogerson was appointed court physician in 1769. In the next year, John Robison, relinquishing his lectureship in chemistry at Glasgow University, accompanied Admiral Sir Charles Knowles to Russia, to take up a post at the Imperial Sea Cadet Corps of Nobles- possibly escorted by another Scottish doctor, Matthew Guthrie, who was returning to St Petersburg with an MD diploma from St Andrews University. Guthrie was to play an important part in Scottish-Russian medical relations. There was certainly a close friendship, cemented by family ties, between him and Robison, who also wrote that Rogerson's "Society and freindship [sic] were the chief comforts of my Life while I was in Russia"."

\footnotetext{
*John H. Appleby, MA, PhD, 51 College Road, Norwich, Norfolk NR2 3JP.

${ }^{1}$ Edinburgh University Library (hereinafter EUL), MS.Gen.873/2, ff.123-124, Grieve to Black, Riga, 29 May/9 June 1783.

${ }^{2}$ Eric Robinson and Douglas McKie (editors), Partners in science. Letters of James Watt and Joseph Black, London, Constable, 1970, pp. 153-154.
} 


\section{J. H. Appleby}

Rogerson was nominated Catherine's physician during 1773, the year Robison left Russia for the professorship of natural philosophy at Edinburgh University. At the Russian court, Rogerson exercised considerable influence over the empress. For instance, he not only brought to her notice the historical works of William Robertson, but also obtained in return journals and a chart of the Russian discoveries in America, which Rogerson incorporated, with acknowledgements, in his History of America (1777). For these and other services, Rogerson was elected to the Russian Academy of Sciences in December 1776-the first Briton so honoured. His introduction to Princess Dashkova by Admiral Knowles's wife in the spring of 1772 led to Dashkova's correspondence with Roberston and Robison regarding her son Paul's education at Edinburgh University. She and her son spent the years 1775-79 at Edinburgh, a period described in her memoirs as "the happiest and most peaceful that has ever fallen to my lot in this world". She had frequent contacts with Robertson, Black, and other distinguished Scots, while it was on the orders of her own physician, William Cullen, that she went to take the waters at Buxton and Matlock in $1778 .^{3}$ The Dashkovs' three years at Edinburgh had a very favourable effect upon Russo-Scottish relations. These were further strengthened by Dashkova's appointment as president of the Russian Academy of Sciences and, from its inception on 30 September 1783, of the Imperial Russian Academy. Black and Robertson were elected foreign members, having been proposed by Dashkova, who wrote to Black in February 1783, inviting a scientific correspondence.

However, the fame of Joseph Black's discoveries had reached Russia long before 1783. Two Russian students, for example, Semyen Desnitsky and Ivan Tretyakov, attended his winter $1764 / 5$ class at Glasgow University and were afterwards specifically mentioned by Black as having heard him elucidate his latent heat theories. ${ }^{4}$ Robison himself told Watt that "Dr. Kruse (a Gentleman eminent in that Country for Steel Works and great Knowledge in Chemistry, Magnetism etc.) ... was very inquisitive about your discoveries, and was not unskilled (thro' my information) in Dr. Black's Theory ...." Kruse was a Russian Academician and physician to three sovereigns, Elizabeth, Catherine, and Paul. Then, of course, there were the Dashkovs and the Scottish physicians in Russia who helped to spread Black's fame.

Of potentially greater significance, however, is the fact that Catherine the Great invited Black, professor of medicine and chemistry, to set up a "Medical and Chymical Seminar" in St Petersburg, as transpires from a letter addressed to him on 20 March 1783 by George Blake, a Hammersmith brewer. Blake suggested that, in the light of this invitation, Black might consider "the Propriety of a Proposition to ye Empress of Russia to introduce the art of brewing Malt Liquors of any desired Species into her Dominions", especially as an antiscorbutic for the navy ${ }^{6} \mathrm{He}$ had met Black, briefly, in June 1782 , so that it is possible that the invitation had been

\footnotetext{
${ }^{3}$ Kyril Fitz Lyon (translator and editor), The memoirs of Princess Dashkova, London, Calder, 1958, pp. 139 (Rogerson) and 147. Prince Paul Dashkov, the first Russian to graduate at Edinburgh University (MA in classics, April 1779) was made a fellow of the Royal Society of London in 1781.

${ }^{4}$ Robinson and McKie, op. cit., note 2 above, p. 84.

'Ibid., p. 248.

${ }^{6}$ EUL, MS.Gen.835/2/139, ff. 115-116.
} 


\section{John Grieve's correspondence with Joseph Black}

extended shortly before then. Blake, an experienced brewer who had devised a new system of brewing beer for the British navy when he supervised the "Kings Brewery for the Use of the Navy" for two years, wrote again to Black, in June 1783, thanking him for his reply of 24 March and pointing out that he had not "fully concluded on soliciting your interest at Petersburg for my attempting to introduce the Art of Malting and Brewing on the English Principles". " The outcome is not known, but it may be because Black declined the empress's proposal that two Russians were sent in the summer of 1784 to study at the London School of Practical Chemistry, run by Dr Bryan Higgins, and to make a special report of British techniques of brewing beer and distilling spirits. ${ }^{8}$ As well as the invitations issued by Catherine to Black and to Watt (in 1771 and again in 1775), she extended one, in 1787, through Princess Dashkova, to James Hutton, who had earlier catalogued the princess's Derbyshire minerals. ${ }^{9}$ Had the trio been tempted over to Russia, it would have dealt a serious blow to the scientific achievements of the late Scottish Enlightenment.

Before finally setting the stage for John Grieve's correspondence with Joseph Black, it remains to trace his early career. Born at Edinburgh in 1753, Grieve studied natural and moral philosophy, logic, mathematics, and the classics at the university prior to taking up medicine between 1775 and $1778 .{ }^{10} \mathrm{He}$ joined the Edinburgh Physico-Surgical Society in July 1774 , becoming its president in 1776 . For some reason, he did not graduate at Edinburgh; instead, he was awarded the MA and MD degrees of Glasgow University in October $1777 .^{11}$

In March 1785, the Rev. Dr William Adams, master of Pembroke College, Oxford, and a lifelong friend of Samuel Johnson, wrote to James Boswell at Edinburgh asking him to contact the provost and William Robertson about John Grieve's character and career, at home and abroad. This information was required for a friend who was making a special investigation and who insisted upon strict anonymity, refusing to disclose even the purpose of the enquiry. Accordingly, Boswell wrote to "Principal Robertson to inform me about Dr. Grieve of Russia" at the end of April 1785 and, on 2 May, to Sir Alexander Dick, former president of the Royal College of Physicians of Edinburgh. The letter to Robertson and his reply have not survived. However, Dick's answer, dated 1 June 1785, sheds light on how Grieve came to be in Russia. ${ }^{12}$

Mr Mitchelson my Doer introduced him [Grieve] to me by a Letter desiring me if after conversing with him I could recommend him to Admiral Greig as a Physician versed likewise in Surgery who desired to be employed in any considerable charge in Russia. I thought such an enquiry deserved

\footnotetext{
${ }^{7}$ EUL, MS.Gen.873/2, f. 125. Blake wrote two books about his brewing system, for which he invented a special hydrometer and saccharometer.

'A. G. Cross, 'By the banks of the Thames'. Russians in eighteenth-century Britain, Newtonville, Mass., Oriental Research Partners, 1980, pp. 78-79.

${ }^{9}$ EUL, MS.Gen.873/3, ff.36-39, Black to Princess Dashkova, 27 August 1787.

${ }^{10}$ For a good account of medical education at Edinburgh University, and what the syllabus of the four faculties of medicine, the arts, law, and theology entailed, see an anonymous letter by a graduate in Med.Phys.J., 1801, 6: 301-308.

${ }^{11}$ Grieve's very well-preserved educational documents and scrolls, complete with seals, are in the custody of his descendants.

${ }^{12}$ Marshall Waingrow (editor), The correspondence and other papers of James Boswell, New Haven, Conn., and London, Yale University Press, 1969, vol. 2, pp. 83-84.
} 
two or three sittings before the Picture I was to draw of him to the Admiral would be compleat $\&$ that Dr Rogerson the Empress's Physician might be solicited to be his Friend . . .. I at last gave him a letter to the Admiral which happened to be the foundation of his Fortune for Dr Rogerson finding him a fit person to be trusted recommended him to the Empress's Generals of her forces in the Ukraine...

Dick added that he considered Grieve to be "a man of Parts". ${ }^{13}$

Grieve went to Russia in June 1778, serving as a military doctor in the Voronezh Division until March 1783, when he returned because of his health. In addition to Black's diploma, he was conveying a "Scotch packet", with a letter of introduction from Rogerson to John Clerk of Penicuik, ${ }^{14}$ and a report by Matthew Guthrie, by then chief physician to the Imperial Land Cadet Corps of Nobles at St Petersburg, of his experiments in freezing mercury along the lines suggested by Black. Grieve, however, was detained in London, reaching Edinburgh only towards the end of 1783.

At about this time, Grieve's case history of his treatment of a Russian woman for obstinate dropsy appeared in Andrew Duncan's journal Medical Commentaries in the form of of a letter, ${ }^{15}$ and was widely circulated by British and German medical periodicals. Grieve stayed in Edinburgh with Dick, who secured his election on 13 January 1784 to corresponding membership of the Society of Antiquaries of Scotland. On 1 February, he was made an Edinburgh burgess and guild brother. ${ }^{16}$

While he was in Edinburgh, John Grieve visited Black, who provided him with an introduction to Jean-Joseph Suë, an eminent professor of anatomy at the Collège Royal de Chirurgie in Paris. Primed by Black to give "some Account of such Books and Discoveries as from their Novelty are become here the objects of general Attention", Grieve admitted in a letter from Paris on 11 May 1784 that he found the task more difficult than he had anticipated, for "the Discoveries in Physickes, which have been lately announced to the Public are many of them so extraordinary a kind, and hitherto so little ascertained, that I am often at a loss to judge whether they are fitter objects of belief or ridicule ...."

However, in this letter, and in his next one to Black upon his return from France, Grieve gave some excellent descriptions of scientific and medical developments.

\footnotetext{
With respect to the Balloons, which are now scarcely ever mentioned in Paris, there is an Account, in the last Mercure de France of a method of conducting them in all different directions, \& even against the wind. The experiment is said to have been made in presence of Mongolfier, who with several others subscribed to the truth of it. The Inventor is of Lyons and it was there the trial of it was made-his name is Mercie - his method is still a secret. The chemical experiments made by Lavoisier and Meunier, on Water, are if I forget not, already known to you, but lest they should not, I have transmitted a copy of the Journal in which they are announced to Mr. Henry Mackenzie from whom you may receive it. The particulars of their process have not yet been published, but the conclusion drawn from them, viz that Water is composed of Dephlogisticated and Inflammable airs does not meet with general credit in this place.
}

${ }^{13}$ Dick to Boswell [in London], Prestonfield, 1 June 1785, C.997. Prof. F.A. Pottle's transcript. Printed with permission of Yale University and the McGraw-Hill Book Co. (William Heinemann Ltd).

${ }^{14}$ Scottish Record Office (hereinafter SRO), MS.GD.18/5121, f.3, Rogerson to Clerk [n.d.], but $c$. May 1783.

${ }^{15}$ Med. Comment., 1783-84, 9: 286-302.

${ }^{16} \mathrm{~J} . \mathrm{H}$. Appleby, 'British doctors in Russia, 1657-1807: their contribution to Anglo-Russain medical and natural history', University of East Anglia thesis, June 1979, pp. 193-197. 


\section{John Grieve's correspondence with Joseph Black}

In the Journal de Paris of today one of the name of Carra relates two singular experiments. In the first he put one part of oil of Vitriol and two parts of Water in a vessel (bacquet) into which he introduced a rod of iron bent at right angles in such a Manner that one end remained in the fluid Mixture, while the other was applied to his Stomach-the consequence, he says, was that in about a quarter of an hour, he felt a heat which he qualifies with the words douce et penetrante, diffuse itself over his whole body - this effect he attributes to the inflammable gas conveyed along the iron. This second Experiment was with Electricity - on applying his hand to the back of a Person seated on the insulated chair the person felt the usual, prickling sensation, following the direction of the hand, which ever way it was moved; but on making the same movements with his hand after putting some crude Sulphur into the arms of his coat, the above Sensations increased in a very great proportion in so much that several people by these means, from being cold, were made to sweat in the space of a few minutes - he calls this Electricite Magnetizante and proposes, to publish, in a short time some farther experiments with it.

But what of all others forms the most frequent subject of conversation here at present, is the Magnetisme Animal as it is called of one Mesmer, a German physician. He has published a short account of his System, which I would have sent you, had it been possible to get a copy of it. The substance of it is, 'That there is a subtile fluid which fills the Universe; which constitutes a connecting medium between us and the heavenly bodies, and between us and the earth. He said that this fluid is capable of receiving, propagating, and communicating impressions, at any distance, and that the consequent notions are subject to mechanical laws. He says he has discovered means by which he can direct the course of this fluid, accumulate it in one body and convey it to another at pleasure. And from its singular effects on Animal bodies, he has called it Animal Magnetism, as well as on Account of its having Poles like the magnet. He ascribed many diseases to the unequal distribution of it, and offers to cure many by restoring the equilibrium. His System, singular as it is, has more friends than enemies - his house is so much crowded that there are seldom fewer than two hundred people in it at one time, and that in succession from morning to night, all of whom undergo his operations. When you are told that he has five guineas the first month, and four every subsequent one, from each patient; that he has already sold his Secret to above a hundred and fifty persons for a hundred guineas each, and that he cannot admit the number of Purchasers, they are so frequent, you will judge what an immense fortune he is likely to make in a short time. I was in his house the other day, and was witness to his method of operating. In the middle of the room is placed a vessel of about a foot and a half high, which is called here a bacquet, it is so large that twenty people can easily sit around it. Near the edge of the lid which covers it, there are holes pierced corresponding to the number of persons who are to surround it. Into these holes, in the manner of Carra's experiment above mentioned are introduced iron rods bent at right angles outwards, and of different heights so as to answer to the part of the body to which they are to be applied. Besides these rods, there is a rope which communicates between the bacquet and one of the Patients; and from him it is carried to another; and so on the whole round. The most sensible effects are produced on the appearance of Mesmer, who is said to carry the fluid by certain motions of his hands or eyes without touching the person. I have talked with several who have witnessed these effects, who have seen convulsions occasioned and removed by a movement of the hand. In order to qualify this account, which will appear incredible if not ridiculous, I shall add the answer of Mr Le Roi the Academician to my question 'What he thought of it?' He has been appointed one of the Commisioners to examine into the operations of one Deslon who is a Scholar of Mesmers. His words were these 'Je n'en puis pas encore juger; mais j'ai déjà vues des choses très singulières. ${ }^{17}$

At the end of this letter, Grieve wrote that, since he had not come across new books on chemistry worth notice, he was enclosing a catalogue so that Black could judge for himself. Grieve promised to keep him posted about any further developments in the subjects described. As good as his word, Grieve wrote again to Black in October from the home of Baron Thomas Dimsdale, who had inoculated Catherine for smallpox in 1768.

Since my last letter I had frequent opportunities of seeing Mr. Lavoisier, and of visiting him at his house. It gave me much pleasure to hear the honorable mention he made publickly of your name,

${ }^{17}$ EUL, MS.Gen.873/2, ff. 171-173, Grieve to Black, Paris, 11 May 1784. 


\section{J. H. Appleby}

acknowledging you, in presence of several Academicians, and other Persons of distinction as the Author of all those discoveries in Chemistry, which have of late years made so happy a revolution in that science. They seemed all to expect you there last summer, I know not on what authority. Mr. Lavoisiers paper on the Decomposition of water was not published while I was in Paris, otherwise I should have brought you a copy of it. I forget whether you advised me only to buy it for myself. If the former, my copy is at your service. Should it be convenient for you to write me, please also to inform me whether Dr. Clarke has brought over the reports of the French Societies on the Animal Magnetism, as a copy sent me by Principal Gordon thro' him, shall also accompany the above. In the mean time I shall only tell you, that they have all agreed in declaring the extraordinary effects produced by the Mesmerism treatment to result from an imaginary not a real Physical agent - and that the convulsions occasioned by it, are not salutary crises but really pernicious. From the opportunities I had of examining it I was enabled to form the same judgment, more than three months ago, and wrote to Mr. Mackenzie accordingly.

As Mr. Argaund the inventor of the new Lamps is come to London, and is joined with Mr: Parker the Glass Manufacturer in a Patent for them, you either do already, or soon will know them. The principle on which they are made is simple, and the effect highly advantageous and beautiful - by placing the wick in a circular form round a hollow cylinder, and thereby establishing a current of air from below, to the inside of the flame; this added to the ordinary current from without increases the light in proportion of nearly ten to one, and as the heat is equally augmented, the smoke is totally consumed. Mr. Argaund is a native of Geneva and is well known for his skill in Chemistry and all the older branches of Natural Philosophy.

Before I left Paris, there was one Bienvenu who shewed a flying machine, without any reference to the Balloons but which I think might be applied to the direction of these: it consisted of four wings like so many inverted kites fixed to an axis at angles of about 45 degrees. These were found, on the circular motion of the axis, to act on the air like the perpetual screw of Archimedes, and that in any direction. To exemplify this, he had a spring like a bow tied to the lower end of the axis, the spring of which, being fixed to a circular piece of wood upon the axis, resembling a pulley, and being wound upon this, was no sooner let go than the two ends of the bow receding from each other turned round the axis, and with it the wings. In this manner, the machine flew the height of about ten feet. I have enclosed a very crude sketch of it. ${ }^{18}$

Grieve's two letters reveal a journalistic knack for highlighting topical trends in the making. They provided Joseph Black with a rich crop of useful information about a wide variety of developments on the Parisian scientific scene.

Grieve was elected to the fellowship of the Royal Society of Edinburgh, along with the outstanding naturalist P.S. Pallas, on 26 January 1784 - the first elections since the inaugural meeting in June 1783. Black had largely engineered this honour and later, on 12 July, he read to the Society Grieve's paper about kumis - fermented mare's milk. In his next letter to Black, dated London, May 1785, Grieve asked him if and when his paper would be printed in the Society's Transactions, because he was contemplating publication of a separate treatise, incorporating additional experiments on different milks. He wondered, too, whether Black himself had experimented with fermented milk. A postscript requested Black to "specify again in your letter the kind of Metallic ores, which you wanted from Siberia, as I can still easily procure them" (probably from collectors like Pallas and Guthrie). ${ }^{19}$ Grieve's uncertainty over the publication of his paper is understandable because it was not until 1788 that it appeared in the first volume of the Transactions of the Royal Society of Edinburgh. He explained in it that when he first thought of using kumis in medicine it was as little known in Russia as in Britain. After a detailed account of the

18 Ibid., ff.195-196, Grieve to Black, Hertford, 8 October 1784.

19 EUL, MS.Gen.874/4, f.17, Grieve to Black, London, 8 May 1785 . Black answered Grieve in May 1785 , but his reply had not been received eight months later. 


\section{John Grieve's correspondence with Joseph Black}

methods employed by the Tartars and the chemical processes of fermenting kumis, he outlined its medical modus operandi and supplied comprehensive case histories of four patients whom he had successfully treated for debility, digestive disorders, consumption, and nervous illnesses. ${ }^{20}$ This paper created considerable interest at the time, medical and other journals vying to report or reprint it, but it was then virtually forgotten until 1881, when George Carrick, physician to the British embassy at $\mathrm{St}$ Petersburg and formerly attached to the Brompton Hospital for Consumption and Disorders of the Chest, stressed that the credit for "being the first to estimate the importance of koumiss as an article of diet, and of discovering its uses as a therapeutic remedy" belonged to Grieve, whose paper was remarkable for the suggestiveness, powers of thought, and originality displayed by the writer ${ }^{21}$ Modern research and practice in the Soviet Union have tended to confirm Grieve's (and Carrick's) findings on kumis therapy.

The Grieve family had links with Bath. In February 1785, John Grieve became a member of the Bath Philosophical and Agricultural Societies. He later read a short paper to the latter, describing a single-horsed plough he had seen on his journey from St Petersburg to Riga in May $1783 .{ }^{22}$ At one time he may have considered settling in Bath. However, it is clear from a letter he wrote to Sir Alexander Dick in May 1785 that although he had contemplated returning to Russia during the summer of 1785, he was in two minds whether to be "on the Banks of the Thames or the Volga". ${ }^{23}$ In the same letter, Grieve asked Dick for the Gaelic and Erse books in his possession to be sent to Dr Rogerson at St Petersburg. The following month, James Cumming, secretary to the Society of Antiquaries of Scotland, wrote to inform Grieve, who was in London, that he was shipping the works procured by Dick and others to the Russian capital. ${ }^{24}$ The reason is made clear by Rogerson's letter to William Cullen of 27 July, in which he enclosed, for Dick's attention, the prospectus of Catherine's project for comparing different languages. ${ }^{25}$ Its result was the lavish Linguarum totius orbis vocabularia comparativa, compiled by Pallas and published between 1786 and 1789, which paved the way for comparative linguistics in Russia. ${ }^{26}$ The episode is a good illustration of Scottish-Russian co-operation by five medical men (including Pallas).

\footnotetext{
${ }^{20}$ John Grieve, 'An account of the method of making a wine, called by the Tartars koumiss; with observations on its use in medicine', Trans. R. Soc. Edinb., 1788, 1: 178-190. For further commentary, see Appleby, op. cit., note 16 above, pp. 206-212.

${ }^{21}$ George L. Carrick, Koumiss ... and its uses in ... pulmonary consumption and other wasting diseases, Edinburgh and London, 1881, pp. 12-13. Author's presentation copy to Sir Joseph Fayrer in the Wellcome Institute Library.

${ }^{22} \mathrm{~J}$. Grieve, 'A description of the Russian ploughs', letter dated 21 November 1785, Letters and Papers on Agriculture, Bath Society for the Encouragement of Agriculture, Arts, etc., 1801, 3: 368-370.

${ }^{23}$ SRO, MS.GD.331/42/3, Sir Alexander Dick's Papers, Grieve to Dick, London, 19 May 1785.

24 EUL, MS.Laing 2/82, Cumming to Grieve, [Edinburgh], 13 June 1785.

${ }^{25}$ Rogerson to Cullen, St Petersburg, 27 July 1785/7 August 1785, in John Thomson, An account of the life, lectures, and writings of William Cullen, MD, 2 vols., Edinburgh and London, William Blackwood, 1859 , vol. 1 , pp. $642-643$.

${ }^{26}$ Royal College of Physicians of Edinburgh Library (hereinafter RCPEL), MS.Ab.4.53, 'Letters to Dr Cullen 1774 to 1790 '. This volume contains Rogerson's letter and the prospectus by Pallas, dated St Petersburg, 22 May 1785, 6 printed pages in French. Sir Alexander Dick died in November 1785, which is perhaps why Cullen retained Pallas's prospectus for this publication.
} 


\section{J. H. Appleby}

Grieve's last surviving letter to Black is dated London, 25 January 1786 . Here he explained that he had not published his separate treatise on kumis because he was still awaiting a reply to his previous letter, and had only recently heard that Black had replied long ago, without the letter reaching him. He was making, he wrote, some additions to his kumis paper and wanted to know the Society's "disposition" about an independent publication. Black indicated on Grieve's letter that he answered it on 31 January 1787 . This letter has not been preserved, but presumably Grieve was dissuaded from publishing a separate treatise. As he told Black, he had finally decided to settle in London for private practice. ${ }^{27}$ Over the next eight years, he was elected to no less than eight metropolitan societies, culminating with the fellowship of the Royal Society. In 1798, he returned to Russia as court physician, first to Paul and then to Alexander, dying suddenly, at only fifty-two years of age, in December 1805.

Matthew Guthrie, Grieve's colleague, was also responsible for communicating through his writings a great deal of expert information about Russian medical, natural, and cultural history. Many of his letters were published in Medical Commentaries; James Anderson's journal, the Bee; the Philosophical Transactions; and the Transactions of the Royal Society of Edinburgh. ${ }^{28} \mathrm{He}$ also corresponded with Joseph Black. It will be recalled that Grieve conveyed, part of the way from Russia, Guthrie's letter to Black of 23 January 1783, reporting his experiments in freezing mercury at St Petersburg along lines suggested by Black, who, in his turn, quoted excerpts from it in his lectures on the 'General effects of heat' and 'Some examples of latent heat'. ${ }^{29}$ A copy of this letter was also shown to John Robison, who had informed Guthrie that Black intended to pass on his own observations on Guthrie's experiments; Guthrie asked Black to send them before the winter of 1783/4, when he planned to pursue his researches. ${ }^{30}$ Most of Guthrie's subsequent papers about freezing mercury were communicated to the Royal Society of London, Grieve attending the one read on 25 March 1784. Black also quoted extensively from a letter that Guthrie wrote to him later, probably at the beginning of 1793 , headed 'Powerful frigorific mixtures'. ${ }^{31}$

Both Matthew Guthrie and John Rogerson were involved with a famous Russian medicine - the Bestuzhev Drops (Tinctura tonica nervina Bestucheffii), named after the statesman, Count Aleksey Bestuzhev-Ryumin, who invented them in 1727. Guthrie wrote in 1786 to thank Black for his "friendly care" of Mrs Guthrie. She had returned to Russia much better in health, and, although since troubled by "strong Hysteric Spasms" on menstruating, treatment with the Bestuzhev Drops had fully restored her. This "martial Tinct.", Guthrie pointed out, "which our Empress purchases from the hands of your celebrated brother Moudel [sic] for the public use,

${ }^{27}$ EUL, MS.Gen.874/4, ff.27-28, Grieve to Black, 25 January 1786.

${ }^{28}$ For Guthrie's career and output, see Appleby, op. cit., note 16 above, p. 230, footnote 1 (published sources), pp. 230-280, 283-287, 331-336, 350-370.

${ }^{29}$ EUL, MS.Gen.875/2, ff.83-86, Guthrie to Black, St Petersburg, 23 January 1783. Ibid., in Black's hand, 'Extracts from Dr Guthry's [sic] letter ... Freezing of mercury experiments ...', in John Robison (editor), Lectures on the elements of chemistry, delivered in the University of Edinburgh by the late Joseph Black, $M B$, Edinburgh, 1803, vol. 1, pp. 75, 137-138.

${ }^{30}$ EUL, MS.Gen.874/4, ff.7-8, Guthrie to Black, St Petersburg, 22 September 1783.

${ }^{31}$ Black's lectures, op. cit., note 29 above, p. 136. 


\section{John Grieve's correspondence with Joseph Black}

is in much repute here, indeed I think it has good effects in what are commonly called Nervous diseases." 32 Replying, eight months later, Black expressed his curiosity to "see the Remedy which has done her good . . . I believe the process for using it is not publickly known."33

Another subject of Matthew Guthrie's correspondence with Black concerned the reasons given by an "ingenious proprietor of an Iron fabric" near St Petersburg for his claim, based on observation, that "Phlogiston is not the only principle concerned in the conversion of Iron into Steel", the best steel being produced by birch charcoal..$^{34}$ Three years later, Guthrie reported to the effect that an industrial friend in Siberia had written to him about a method of "making Barr Iron directly from the first fusion, without going through the process of casting"-and this without any knowledge of Cort's parallel process in Britain. ${ }^{35}$ Black replied, acknowledging Guthrie's "repeated agreeable letters" and explaining points of similarity between the two processes; he stressed, however, that he needed more particulars in order to form an adequate judgement. ${ }^{36}$

So far, Grieve's and Guthrie's correspondence with Joseph Black has been discussed in the context of medical intercommunication between Scotland and Russia. But what about the reverse-Russo-Scottish contacts? Until the 1780s, these were virtually non-existent, but over the decade the situation changed significantly. Professor Cross has shed fresh light on Russian medical students at this period; ${ }^{37}$ Daniil Pischekov, for instance, who is mentioned in the letter Grieve wrote to Black from Dimsdale's home at Hertford. Pischekov studied medicine at Edinburgh University from 1783 to 1785 and was awarded an MD by the University of Aberdeen in 1784 - the third Russian to gain an MD from a Scottish university. His thesis, 'De novo methodo psoram sanandi', received wider publicity through a letter from a "Medicus" at Edinburgh, which appeared in the Gentleman's Magazine for February 1786. Referring to recent correspondence in the journal about remedies for the "cure of itch", "Medicus" described a simpler alternative medicine, vegetable acid, which Pischekov pioneered in Russia and outlined in his dissertation.

\footnotetext{
${ }^{32}$ EUL, MS.Gen.873/2, ff. 276-277, Guthrie to Black, St Petersburg, 20 October 1786. J.G. Model, first apothecary to the empress and professor at the Russian Academy of Sciences, enjoyed a European reputation as a pharmacist. His Récréations physiques, économiques et chimiques, translated from the German in 1774, contains four letters about the Bestuzhev Drops. From them, it emerges that Empress Elizabeth persuaded Count Bestuzhev-Ryumin to communicate the secret process to Model, who later obtained his permission to reveal the formula to his own son-in-law, Jean Christian Durop, chief of the St Petersburg Admiralty Apothecary. Regrettably, Model's assistant decamped with the formula and sold it to General la Motte in France, where it was marketed very profitably as General la Motte's Drops. Catherine the Great used Rogerson's diplomatic skills to buy the secret from Durop's widow for a considerable sum, ordering the prescription to be published in the St Petersburg Journal for 1780. See also M.H. Klaproth, 'Geschichte der Bestuscheffchen Nerventinctur und der Lamothischen Goldtropfen', Neue Beiträge zur Natur- und Arznei-Wissenschaft, 1782, 1: 137-157.)

${ }^{3 s}$ EUL, MS.Gen.873/2, ff. 278-279, Black's draft reply to Guthrie, [Edinburgh], 20 August 1787.

${ }^{34}$ Loc. cit., note 30 above.

${ }^{35}$ Loc. cit., note 32 above.

${ }^{36}$ Loc. cit., note 33 above. Cort's process is described in Black's lectures, op. cit., note 29 above, vol. 2 , pp. 496-498, and discussed in three letters, dated 6 October and 5 November 1784 and 2 June 1787, from Black to his brother Alexander, Black's letters and papers, Public Record Office of Northern Ireland, MS.T.1073, nos. 28, 29, 31.

${ }^{37}$ Cross, op. cit., note 8 above, pp. 139-141.
} 


\section{J. H. Appleby}

While a surgeon in 1780 in southern Russia, Pischekov devised baths made of the residuum ("barda") from distilled spirits, obtained from distilleries, as a very effective and cheap cure for the itch, requiring no sulphur applications. In villages where he had been unable to procure this substance, he had used the common Russian drink called kvas (beer made from barley, malt, and rye), which had proved equally efficacious. ${ }^{38}$ Five years after his return to Russia, Pischekov published Karmanny lechebnik (1790), basically a translation of Sir John Elliott's Medical pocket-book (1781), but with additions and prescriptions of his own. ${ }^{39}$

Iurii Bakhemetev, another Russian student, who arrived at Edinburgh in 1780, was elected to the Medical Society in December 1783 and to the Natural History Society a year later, becoming its president in 1785 . His thesis, 'De variolis inserendis', which he defended in 1786, referred to Dimsdale's writings on inoculation; he was also awarded an MA that year by St Andrews University.

Pavel Bakunin, yet another Russian studying medicine at Edinburgh University between 1785 and 1787, was potentially the most influential of them all. His meteoric career began in Scotland: on 22 January 1787, he was elected a foreign fellow of the Royal Society of Edinburgh and on 12 June he became a corresponding member of the Society of Antiquaries of Scotland. Then, in 17.94, when only thirty-two years old, he replaced Princess Dashkova as director of the Imperial Academy of Sciences. Unfortunately, he died in 1805.

Strangely enough, the most palpable impact upon Russo-Scottish medical exchange was made by a Russian doctor who never set foot in Scotland, nor was ever honoured by the Scots. This was the Ukrainian-born Danilo Samoilovich who, as a surgeon, had played a conspicuous part in the Moscow plague of $1771 .^{40} \mathrm{Having}$ been granted paid leave in $\mathbf{1 7 7 8}$ for medical studies abroad, Samoilovich received an MD at Leiden in $\mathbf{1 7 8 0}$ for a dissertation on obstetrics. He travelled widely through Europe and, in May 1783, he wrote to Cullen from Paris about arrangements for sending four of his published works on the plague in Russia, his printed thesis, and three tracts by Hugues Maret, the distinguished French epidemiologist. He also invited Cullen and other members of the Royal College of Physicians of Edinburgh to correspond with him. He had hoped, he wrote, to visit London in April of that year and to spend the winter at Edinburgh University, but had received no reply from the Russian Medical College to his request for permission to make the journeys. ${ }^{41}$ That Cullen valued Samoilovich's letter is suggested by the following circumstance. Craig has remarked that in 1771, the College of Physicians of Edinburgh received a letter from the Lord Provost, urging it to consider "the most effectual means to prevent the

\footnotetext{
${ }^{38}$ Gentleman's Magazine, 1786, 56: 130-136.

${ }^{39}$ Other books by Scottish medical writers, which were translated into Russian at this time included Francis Home's Principia medicinae (in 1786) and John Gregory's A father's legacy (in 1791). William Buchan's celebrated Domestic medicine was also rendered into Russian and published in four volumes by the Moscow University Press between 1790 and 1792. No Russian household was considered complete without a copy; indeed, Catherine was so pleased with it that she sent Buchan a gold medal and a complimentary letter.

${ }^{40}$ For a balanced and comprehensive account of Samoilovich's career and writings, see the entry on him by John T. Alexander in The modern encyclopaedia of Russian and Soviet history, New York, Academic International Press, 1983, vol. 33, pp. 73-76.

${ }^{41}$ RCPEL, letters to Dr Cullen, MS. Cullen 31(10).Ag.2.10, Samoilovich to Cullen, Paris, 29 May 1783 (the original).
} 
plague at present raging in other countries from taking place" in Edinburgh. A College committee advised the president who was asked to reply, but in what terms was not recorded. ${ }^{42}$ In fact, all the relevant documents are to be found in Cullen's letter-book, culminating in a 'Memorial' signed by the "Physicians of the Faculty of Physic in the University of Edinburgh": Cullen, Black, Monro, Gregory, Hope, Ramsay, Home, and Young. A fair copy of Samoilovich's letter, plus two extra pages not included in the surviving original, has been attached by Cullen immediately after this 'Memorial'. ${ }^{33}$

William Cullen answered Samoilovich's letter in September 1783, evidently informing him about the activities of the various institutions associated with the College. This transpires from Samoilovich's second letter to Cullen, in which he explained that he would not be visiting "votre célèbre Athènes" because he was obliged to return to St Petersburg at the end of September 1783; he was sending his and Maret's tracts, and if the College members thought well of them, he would be honoured to be elected an "associate" ${ }^{44}$ Samoilovich dispatched the works, ${ }^{45}$ with a similar set of his own writings to the newly founded Royal Society of Edinburgh, at the end of August. ${ }^{46}$

On his return to Russia, Samoilovich was licensed to practise as a doctor and was sent to deal with the plague at Cherson. From here, he wrote again to Cullen in February 1785, asking whether he had been elected to the "Société Royal Philosophique" on the strength of his treatises on the plague, which he had presented, through Cullen, in August 1783. ${ }^{47}$ However, there is no record of Samoilovich having been elected a fellow, or an honorary fellow, of the Royal Society of Edinburgh; nor is there any archival material extant for the relevant period which might have indicated any voting for him. ${ }^{48}$

Samoilovich's letter provided Cullen with details of his career. Prince Potemkin had appointed him senior physician to the two central and south Ukrainian provinces of which he was governor. At Kremenchug, a provincial capital, he had saved 249 out of 489 victims of the plague, and dissected corpses in order to conduct his researches by means of a Dellebarre microscope obtained for him by Potemkin. As he told Cullen, this section of his letter, describing the results of his investigations, was also inserted in his letter of 12 May to the Journal Encyclopédique. Addressed to members of the Royal Society of Medicine at Paris, it also contained a flattering letter from Frederick the Great of Prussia (Potsdam, 6 November 1783) to whom Samoilovich had sent a copy of his Mémoire sur la peste de Moscou, 1771 (Paris,

${ }^{42}$ W.S. Craig, History of the Royal College of Physicians of Edinburgh, Oxford, Blackwells, 1976, p. 181 .

${ }^{43}$ RCPEL, letters to Dr Cullen, MS. Cullen 31(9).Ag.2-9. Some eight connected documents, ending with the 'Memorial'.

44 Ibid., MS. Cullen 32(3).Ab.4.54, Samoilovich to Cullen, Paris, 28 August/8 September 1783.

${ }^{45}$ The tracts are listed in the sale catalogue of Cullen's library, A catalogue of medical books, RCPEL, Cf.4.10, [n.d.], pp. 80 (Maret's) and 111 (Samoilovich's). Cullen's books were sold in Edinburgh between November 1791 and March 1792. (Information kindly supplied by Miss J.P.S. Ferguson, Librarian.)

${ }^{46}$ Trans. R. Soc. Edinb., 1788, 1: 80.

${ }^{47}$ RCPEL, letters to Dr Cullen, MS. Cullen 31(12).Ag.2.12, Samoilovich to Cullen, Cherson, [February] 1785.

${ }^{48}$ Letter from Mr W.H. Rutherford, Executive Secretary, Royal Society of Edinburgh. 


\section{J. H. Appleby}

1783)..$^{49}$ An earlier letter in the same journal, purportedly from a "subscriber" but closely resembling Samoilovich in style and tone, disclaimed a report in the Gazette de Leyde for July 1784 that the plague had broken out again at Cherson -it had been banished, the correspondent insisted, never to return, when Samoilovich arrived on the scene in May of that year. The letter also denied newpaper rumours that Samoilovich was at Cherson in 1783 and had inoculated plague victims. ${ }^{50}$

Samoilovich's fourth and last surviving letter to Cullen, dated Cherson, December 1785 , re-echoes his previous one, inviting Cullen's opinions about the results and his theories of his microscopic researches and asking if he should post further writings to the Royal Society of Edinburgh - as a corresponding member. ${ }^{51}$ Whether or not Cullen replied is not known, but there is no doubt that Samoilovich's correspondence and writings, with his flare for publicizing them, interested Cullen and other members of the medical profession in Scotland.

It is worth pointing out that Matthew Guthrie also contributed a letter on the subject of plague quarantines in Russia to Medical Commentaries. Admitting that he would not have ventured to attack time-honoured practices "if I had not the authority of the great Cullen on my side, who has expressed similar sentiments, in his new publication, First lines of the practice of physic", he quoted the appropriate passage in Cullen's work about the justification for safely reducing the period of plague quarantine. His own experience of the plague as a doctor in the Russian army in 1772 had shown him that because a fortnight was the longest period of latency, twenty-one instead of the customary forty days was all that was required to cover the incubation period..$^{52}$

Guthrie made Samoilovich's acquaintance at St Petersburg in about the year 1803. Writing about Cherson harbour, in his own hand, on a interleaved page of the book he edited and published describing his wife's tour of the Crimea in 1795-96, he said: "We have had a very particular account of it from a Gentleman who has just left our Study Doctor [blank] who long had the care of Russian quarantine established in the harbour we are speaking of ...."53 The Russian epidemiologist had been appointed chief doctor of quarantines for the south in 1793 and then, in 1800, inspector of the Black Sea Medical Directorate.

Samoilovich, however, made his greatest mark on Anglo-Russian medical relations in a long letter which he wrote from Moscow in 1791 to Sir Joseph Banks, president of the Royal Society of London, enquiring whether the five sets of his books sent from Paris in August 1783, with an accompanying letter addressed to $\mathrm{Dr}$ Mathew Maty, secretary to the Society, had ever arrived; one set each was intended for the libraries of the Royal Societies of London and Edinburgh, another for

10 J. Encyclopéd., 1785, 6: 115-122.

${ }^{\text {so }}$ Ibid., 1785, 2: 145-147, letter dated Cherson, 5 August 1784.

${ }^{51}$ RCPEL, letters to Dr Cullen, MS. Cullen 32(1).Ab.4.52, Samoilovich to Cullen, Cherson, 12 December 1785. 1985 is the 275th anniversary of William Cullen's birth.

$s=$ 'Observations on the plague, quarantines, \&c. in a letter from Dr Matthew Guthrie to Dr Duncan', Med. Comment., 1787, 8: 345-363. William Cullen, First lines on the practice of physic, 3rd ed., Edinburgh, 1781, p. 19. John H. Appleby, 'A survey of some Anglo-Russian medical and natural history material in British Archives', in J.M. Hartley (editor), Study of Russian history from British archival sources, London, Mansell, 1985, text to note 48.

${ }^{\text {s3 }}$ A tour, performed ... through the . . Crimea by Mrs Maria Guthrie . . .. London, T. Cadell, 1802, British Library ref. 10290.g.3, Matthew Guthrie's autograph interleaved copy, opp. p. 95. 


\section{John Grieve's correspondence with Joseph Black}

William Cullen, a fourth for Baron Dimsdale, and a fifth for Count Vorontsov, the Russian ambassador to London. Samoilovich informed Banks in detail about his researches into the plague and asked the president about the prospects for election to the Royal Society. But the main content of this letter concerns Samoilovich's meeting with John Howard. While he was supervising the General Military Hospital at Vitovka/Bokoiaulenskoye, some forty miles from Cherson, during the Russo-Turkish War (1787-92), he experienced, he wrote, one of the greatest pleasures in his life when Howard, who had read two of his volumes on the plague and had come specially to discuss the subject with him, greeted and presented him with an inscribed copy of his Account of the principal lazarettos in Europe (1789). Howard had even promised to wait for three years till Samoilovich could accompany him to Constantinople, but his death a few days later (on 20 January 1790) from a "fièvre putride" had prevented this. According to a postscript, Samoilovich had also met and discussed the plague with Lady Elizabeth Craven (travelling via Cherson to Constantinople); he had presented her with a copy of his plague treatise and a manuscript of his microscopic researches, and she had promised to engage someone to translate his works into English upon her return to England - a promise which she did not keep.

Banks confirmed in his reply (October 1791) that Samoilovich's books had been received and acknowledgements made in a letter written on 4 November 1783, which must have miscarried. As far as foreign membership of the Society was concerned, Banks said, there was an upper limit of 100 and, although medicine was highly respected, natural philosophy was preferred. Dr Patrick Russell, he added, had recently published an account of the plague in the Levant, and if Samoilovich so desired, he would procure him a copy. ${ }^{54}$

Russell's Treatise of the plague and Howard's Account of the principal lazarettos in Europe both appeared in 1791. The former, the best work on the plague to date and written by a person who had been physician to the British factory at Aleppo, briefly mentions Samoilovich in the context of reinfection and relapse..$^{55}$ In an appendix to Howard's Account, pieced together from rough notes jotted down in his memorandum-book just before his death, the philanthropist paints a very unflattering picture of the military hospitals in Cherson, Vitovka/Bokoiaulenskoye, and the surrounding areas. Samoilovich is not named but is possibly "the physician sent by prince Potemkin". ${ }^{6}$

Nevertheless, apart from Samoilovich's correspondence, many journals such as the Scots Magazine, Medical Commentaries, and the London Medical Journal helped to publicize Samoilovich's works, and he gained a wide medical readership.

\footnotetext{
54 British Library, Add.MS.8097, ff. 427-429. Samoilovich to Banks, Moscow, 19 July 1781, and a copy of Banks's reply, London, 22 September 1791. Royal Society, journal books, vol. 31, p.491, 4 November 1791, Samoilovich's presentation acknowledged. Royal Society, tracts 22/2, 22/3, and 167/3: his presented books. Royal Society, letters 1.39, Samoilovich to Maty, Paris, 29 May 1783 - the letter, with some variations, is virtually identical to the one of the same date from Samoilovich to Cullen (see note 41 above).

${ }^{55}$ Patrick Russell, A treatise of the plague, London, 1791, note on p. 180.

${ }^{56}$ John Howard, An account of the principal lazarettos in Europe, London, 1791, appendix, pp. 18-21. Charles F. Mullett, The bubonic plague and England, Lexington, University of Kentucky Press, 1956, pp. 318-324.
} 